\title{
Regional Aspects of the Development of Clustering in the Dairy Branch
}

\author{
Ivan Novikov \\ Ph.D., Senior researcher at the Volga Research Institute of Economics \\ and Organization of Agro-Industrial Complex (VRIEOAIC) \\ Saratov, Russian Federation, e-mail: novikovis@outlook.com
}

\begin{abstract}
In this paper, we study the classical and modern approaches to the formation of regional agro-industrial clusters. In the current market conditions, the creation of a cluster based on the existing regional infrastructure is impractical. In most cases, clusters are called holding structures that include the full cycle of production, processing and marketing of agricultural products, for example, "dairy clusters" - there are traditional groups of companies that formally follow the classical cluster principles, but do not give individual participants in the production process sufficient organizational and legal autonomy. The conditions for the development of innovation within the cluster, as well as the mechanism for creating the scientific and innovation component of the cluster as a fully-fledged newly created cluster element are investigated. We show that the cluster should be created on the basis and strict adherence to fundamental organizational and economic principles. In particular, while in holdings the economic result of the activity is aimed at achieving the goals of the parent company, in a cluster the maximum interest in the result and the satisfaction of the economic interests of all participants in equal measure should be laid. Moreover, the classical cluster approach in the current market conditions may be unrealizable and the author's concept of cluster development is preferable.
\end{abstract}

Keywords: cluster, rural economy, mechanism

JEL: O13, Q19, R12 


\section{Introduction}

The article examines the current state and trends of the dairy industry in selected post-Soviet countries, reveals the clustering potential, its key advantages and barriers. The article argues that for the full and comprehensive development of both the cluster as a whole and its participants, it is necessary to respect organizational independence and meet the economic interests of all its participants.

These research are based on previous IKED research: Thomas Andersson, Sylvia Schwaag Serger, Jens Sörvik, Emily Wise Hansson (2004), Organization for Economic Co-Operation and Development (2007), Thomas Brenner, Carsten Emmrich and Charlotte Schlump (2013).

These previous studies show that the widespread implementation of cluster policy and the organization of sectoral clusters provide benefits from integration in comparison with traditional forms of management, due to the specifics of production and terms of trade, which in turn reduce the efficiency and economic benefits from production. This study takes another step to assess the importance of clustering, taking into account regional and sectoral specificities based on adherence to key cluster principles. The material for the study was the results of the activities of typical dairy enterprises of the post-Soviet countries (Russia, Belarus, Kazakhstan, Ukraine, Georgia, Turkmenistan) for the period 2001-2017.

The literature on the effect of clusters on the development of competition has drawn attention to the development and deepening of integration processes before evolution into clusters. Research M. Porter (1979-2017), International Organization for Knowledge Economy and Enterprise Development (2004), Organization for economic co-operation and development (2007) and a number of other scientists, in particular, show that the principles of clusterization are obligatory to observe when creating clusters in most industries, regardless of the region of origin. This paper attempts to build on these existing studies, showing that in the context of globalization and corporatization, as well as in the conditions of a significant lag of agricultural science from advanced production and processing enterprises, these principles are not respected, and therefore, it is necessary to focus on organizational autonomy, maximum satisfaction of the interests of the cluster members and the creation of their own scientific and innovative divisions, developing problematic issues based on the industry cluster.

In this paper, we have found convincing evidence that conducting scientific and technical research has a stimulating effect on the modernization of production processes, reduces the cost of research, and also increases the scientific and technological potential of the cluster and its investment attractiveness. This conclusion can have important implications for the management of agricultural enterprises: the conduct of indigenous scientific and technical research can attract large investors to the cluster and stabilize the cluster as a self-sustaining structure, and the potential of the cluster will allow attracting both large business and small but sustainably developing members. enterprises of the industry, creating a natural industry monopoly on the regional market. 
The rest of this document is organized as follows. Section two examines the organizational realities of integration development in the region's livestock industry. Section III introduces clustering methodologies. Section IV describes the proposed model of the sectoral cluster and the science and innovation sector, and Section $\mathrm{V}$ presents the main results and competitive advantages of the proposed cluster.

\section{Organizational realities of development of integration in the animal breeding industry of the region}

Today, the key principles of integration and clustering in the dairy industry of the agro-industrial complex in the post-Soviet states, particularly in Russia, are being implemented at a rather low level. In the course of the research it was revealed that there are key enterprises in the region that are developing in the direction of cluster formation, however, given the market conditions and established organizational and financial relations, it can be stated with confidence that the regional clusters in the dairy industry are in a rudimentary, protocluster state. To date, the following key clustering principles have not been observed in the regional dairy industry:

- there is no mutual interest of the participants in the development of a full-fledged cluster and the deepening of cooperation within the framework of the protocluster;

- members of the dairy subcomplex of the region are not involved in the creation and development of the cluster;

- absent and not ready for the formation of territorial cluster management bodies;

- there is no national program for the development of dairy industry clusters, as key enterprise management is not manifested interest in their formation;

- there are no common approaches to determining the quality of raw milk, as well as wide access to the laboratories by its definition;

- unwillingness of processing enterprises to offer a fair price for raw milk, caused by the presence of a large amount of cheap dry milk of Latin American production, as well as the ability to produce dairy products from by-products using simplified technologies;

- poor performance of agricultural cooperatives due to their absence in a number of regions, as well as low effectiveness of their purchasing and production activities, which translates them into the category of "unstable" suppliers of raw milk;

- shortage of food supply due to unstable weather conditions in a number of regions and the absence of major manufacturers of animal feed, compounded by the high cost of European high-protein feed, vitamin supplements, dressings and mineral complexes, high-demanding industry to feed and their significant weight in the cost of production (about 70\%); 
- the loss of its own breeding base, the gene pool of productive breeds of livestock due to the cessation of the work of most breeding plants, reproducers, control fattening stations, breeding hybrid-breeding centers;

- shortage of qualified personnel (there is no system for industry - specific training of workers and specialists with high education);

- unwillingness of many processing enterprises to cooperate with local agricultural producers, caused by lower prices for freeze-dried milk (Brazilian and Argentine enterprises that have been developing for several decades with the support of national budgets have spent sublimation technologies and, together with the lack of food export restrictions sell cheaper raw milk in Eastern Europe, which at the output gives almost dumping price for freeze-dried milk);

Thus, the current model of the milk protocluster is presented in Fig. 1.

Visually, the current protocluster model demonstrates the absence of a full-fledged cluster structure, which is further complicated by the lack of management initiative on the part of the management of key enterprises in the region to form and subsequently enter a full-fledged dairy cluster.

One of the reasons of this passivity is the objective negative aspects of clustering in a dairy-grocery branches:

- subordination of their own organizational and commercial interests to the interests of the cluster;

- the need to develop production and logistics infrastructure, maintain the quality of products established within the cluster;

- the need to supply agricultural raw materials at prices approved within the cluster, limiting the trade allowance;

- subjective, often imaginary danger of losing legal independence in favor of cluster-forming large enterprises.

At the same time, business entities represented by management underestimate the obvious advantages of creating a dairy cluster:

- organization and increase the efficiency of interaction between the participants of the cluster, the cluster infrastructure, external parties in the process of milk production of added value;

- informational, expert, methodical, consulting support for participants of the dairy cluster, including organization of training, retraining, professional development and training of personnel on the basis of the scientific institutions of the region, studying the problems and prospects of the dairy industry, providing consulting services in the interests of the cluster;

- promote cluster members in bringing to market new products (clean milk production, dairy production «Fitness» series, etc.), the development of cooperation of participants in scientific and technical sphere;

- developing external relations, including the organization of the exhibition and communication measures in the dairy industry, the management of informa- 
tion and communication portal cluster, working media, work with external audiences in terms of attracting the attention of consumers to the novelties of dairy products;

- the creation of a natural monopoly in the dairy-food market due to the quality, price and range of products sold;

- organizational, informational and legal support from the national agricultural authorities on the production, processing and marketing of dairy products, in particular, the organization of fairs, exhibitions and sales of the dairy production.

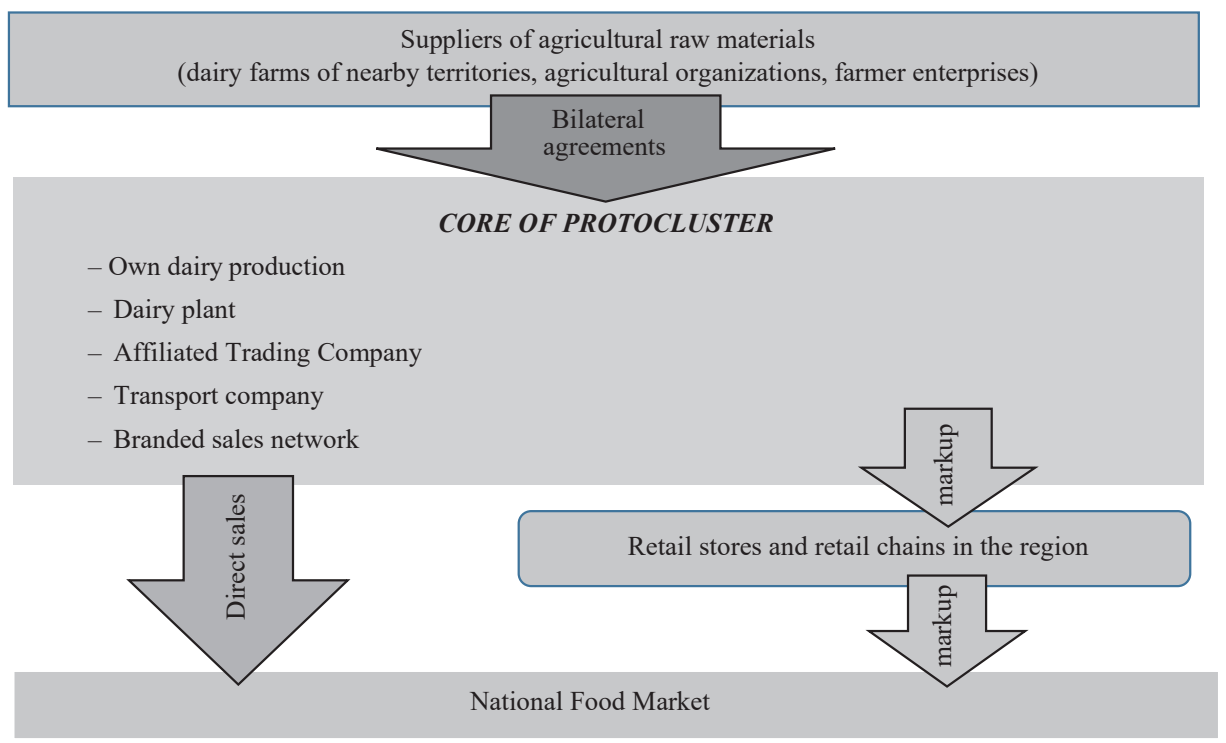

Figure 1. Organizational structure of the milk protocluster Source: authors' own elaboration.

In the course of the research, the structure of value added formation in the dairy-commodity market was analyzed and a significant preponderance was revealed in the cost of finished products of the aggregate trade margin, which indicates insufficient interaction and the lack of coordination between the participants of the protocluster, which allows business entities to overestimate the price of their own products at all stages production cycle of goods (Table 1). 
Table 1. Calculation of value added in dairy products industries (from the calculation of the average price of 2001-2017)

\begin{tabular}{|c|c|c|c|c|c|c|}
\hline \multirow[b]{2}{*}{ Name } & \multicolumn{3}{|c|}{ Specific weight in total value added } & \multirow[b]{2}{*}{$\begin{array}{c}\text { The } \\
\text { total } \\
\text { cost \% }\end{array}$} & \multirow[b]{2}{*}{$\begin{array}{l}\text { Trading } \\
\text { margin \% }\end{array}$} & \multirow[b]{2}{*}{$\begin{array}{l}\text { Market } \\
\text { price }\end{array}$} \\
\hline & $\begin{array}{c}\text { Production } \\
\text { (raw materials) } \\
\%\end{array}$ & Recycling \% & Realization \% & & & \\
\hline Raw milk (3.4\%) & 100 & - & - & 100 & 8.7 & 108.7 \\
\hline $\begin{array}{l}\text { Milk pack } \\
(2.5 \%)\end{array}$ & 44.58 & 46.38 & 9.04 & 100 & 74.2 & 174.2 \\
\hline Kefir (2.5) & 41.95 & 48.81 & 9.24 & 100 & 116.5 & 216.5 \\
\hline $\begin{array}{l}\text { Cottage cheese } \\
(9 \%)\end{array}$ & 36.21 & 54.68 & 9.11 & 100 & 79.3 & 179.3 \\
\hline $\begin{array}{l}\text { Sour cream } \\
(15 \%)\end{array}$ & 64.96 & 25.97 & 9.07 & 100 & 142.0 & 242.0 \\
\hline
\end{tabular}

Source: authors' own calculations.

\section{Methodology clustering mechanism}

The analysis performed allows us to state with confidence that today in the dairy industry there is a need for the evolution of the protocluster into a cluster. The essence of the evolution of cooperative and integrated structures into a cluster is the realization of the potential of the dairy industry and its constituent producers and processors. At the same time, attention is focused not on the targeted support of specific manufacturers or products, but on supporting the accelerated identification and pairing of the economic interests of the economic entities of the industry. At the same time, an increase in procurement prices, a reduction in production costs, and a decrease in trade margins are achieved, which ultimately leads to an increase in production by each specific enterprise and industry as a whole.

Such factors as:

- the conclusion of long-term contracts for solid volumes of raw milk;

- improving the quality and reliability of the rural households produced and purchased in private farms population of milk that meets the requirements of processors;

- creation of a transparent scheme for assessing the quality of purchased milk at the expense of organizing laboratories to prevent conflicts between cluster members;

- formation of a system for promoting marketable products to the market, including taking into account projected consumer preferences.

The growth of the purchase price enable organizations - milk producers to modernize equipment and upgrade the herd, as well as stimulates the owners of private households in rural areas to expand the private utility livestock and implement meas- 
ures to improve safety produced milk (sanitation of the milking procedure, collection and storage of milk, manure removal, creation of an optimal microclimate in the stalls, optimization of the food supply).

Reducing production costs will be achieved through the joint development and implementation of innovative technologies for collecting, storing and processing milk, reducing resource intensity, productivity growth and wages, improving capital productivity, taking into account the characteristics of the cluster.

The firm contractual basis of relations in the cluster will reduce the dependence of raw milk producers on credit resources, eliminating, respectively, the cost of maintaining the collateral base, costs for processing and managing loans, allowing them to accumulate working capital for maintaining expanded reproduction.

Reducing trade margins will be achieved through the joint implementation of rules and procedures governing the production, marketing, logistics, financial and investment activities of cluster members, as well as supporting information exchange between cluster members with each other and government bodies on issues of: quality and safety of products, its certification, availability of various forms of support, requirements for its receipt and execution of various documents and so on.

When creating and developing dairy clusters in national sectoral economies of the region, the key factor should be the maximum allowable agreement and satisfaction of the economic interests of its participants on the basis of long-term cooperation and development agreements. The organizational mechanism of evolution into a cluster will consist of the following key elements:

- forecasting and development of an overall strategy for the development of the dairy industry;

- legal and legislative support for the development of the cluster by the authorities;

- determining the composition of participants on the basis of voluntary coordination of the interests of participants in the dairy industry (holdings and groups of companies, agricultural cooperatives, existing and newly created transport companies, equipped dairy products storage facilities);

- creation and regulation of the logistics network of the dairy cluster (operating in the protocluster, as well as transport companies involved in the cluster);

- administrative support and assistance of national governments, financial and credit organizations;

- conclusion of contracts between the parties, the organization of self-sufficiency;

- development of strategies for the management of expanded reproduction and technological modernization (with the involvement of specialists from scientific and educational institutions of the core area);

- organization of joint work of integrated enterprises;

- ensuring equality in the roles of cluster members among themselves. 


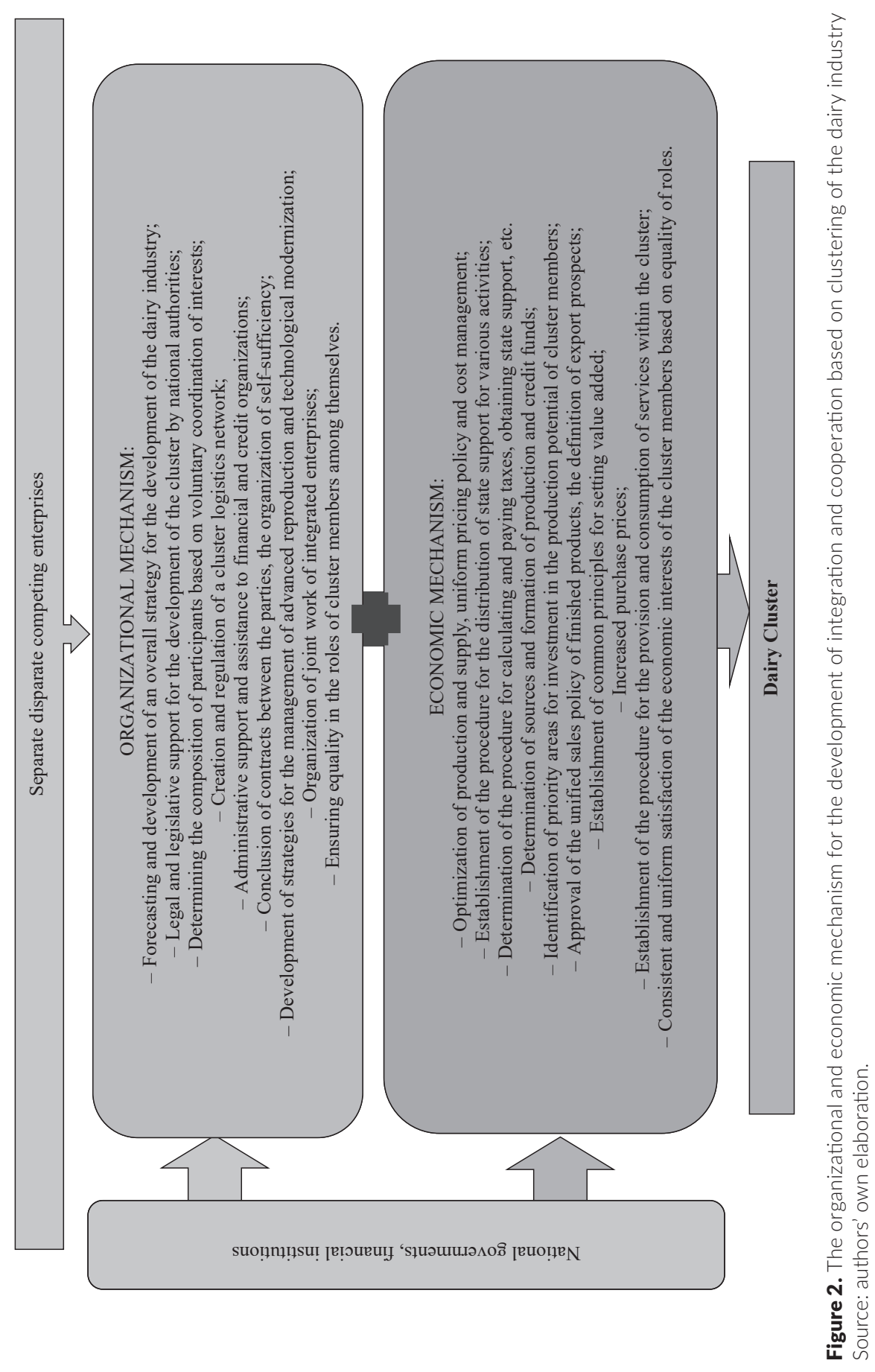


Compliance with these organizational elements will make the most efficient use of the production potential of cluster members, reduce administrative pressure and ensure the establishment of mutually beneficial cooperation of its members to improve the efficiency of the industry as a whole. The economic mechanism for the development of cooperation and integration based on clustering should be based on the following principles:

- optimization of production and supply, uniform pricing policy and cost management;

- establishment of the procedure for the distribution of state support for various activities;

- determination of the procedure for calculating and paying taxes, obtaining state support, etc.

- determination of sources and formation of production and credit funds;

- identification of priority areas for investment in the production potential of cluster members;

- approval of the unified sales policy of finished products, the definition of export prospects;

- establishment of common principles for setting value added;

- increased purchase prices;

- establishment of the procedure for the provision and consumption of services within the cluster;

- coordinated and uniform satisfaction of the economic interests of the cluster members based on equality of roles. (Figure 2)

\section{Model of industry cluster}

As a result of compliance with this mechanism, an individual dairy cluster will appear in the region through self-evolution from the protocluster, Figure 3.

The formed model clearly demonstrates the identified advantages of the cluster and allows its participants to lead an expanded reproduction by achieving a synergistic effect of comprehensive cooperation at all stages of the production cycle of the products produced.

The developed cluster will be a full-fledged, deeply integrated structure, focused on the expanded reproduction of its members and the implementation of a comprehensive modernization of its own capacities at the expense of partially accumulated own profits, partly at the expense of borrowed funds and state support funds.

Research and innovation activities in a full-fledged ideal cluster should be represented by the following participants:

- research institutes;

- experienced laboratories;

- the faculty of higher educational institutions of agrarian profile, engaged in research works; 
- graduate students, undergraduates and graduate students;

- bank of innovations;

- experimental laboratories.

However, today, the region lacks a significant part of the required participants:

- Specialized faculties and scientific laboratories on the basis of large national universities were disbanded, which makes it impossible to involve these institutions in fully participating in the research and innovation work of clusters and the training of highly qualified specialists;

- There are no specialized research institutes dealing with the problems of production and processing of milk and dairy products;

- There is no full-fledged centralized national breeding systems in the region (weakly breeding plants, reproducing stations, stations for breeding work and artificial insemination, and grading of pedigree dairy cattle are unfunctioning or eliminated);

- The faculty of higher educational institutions of agrarian profile, engaged in scientific research, are mostly separated from the production realities and are not ready to carry out research in demand in the dairy cluster today;

- Graduate students, undergraduates of universities and colleges of the region are poorly focused on full-fledged work (including research) in the dairy industry in general and in rural areas in particular;

- There is no full-fledged bank and innovation market in the region, which forces participants in the dairy industry to purchase technologies, equipment and breeding material in other regions, in particular in the EU and the USA;

- Experimental laboratories conduct research on narrow specificity and, due to the high cost of their research, are not available for most participants in the dairy industry in the region.

The above trends hinder the involvement of scientific organizations and universities on an ongoing basis, which, in turn, creates prerequisites for independent research and innovation activities within the cluster. 
Regional Aspects of the Development of Clustering in the Dairy Branch

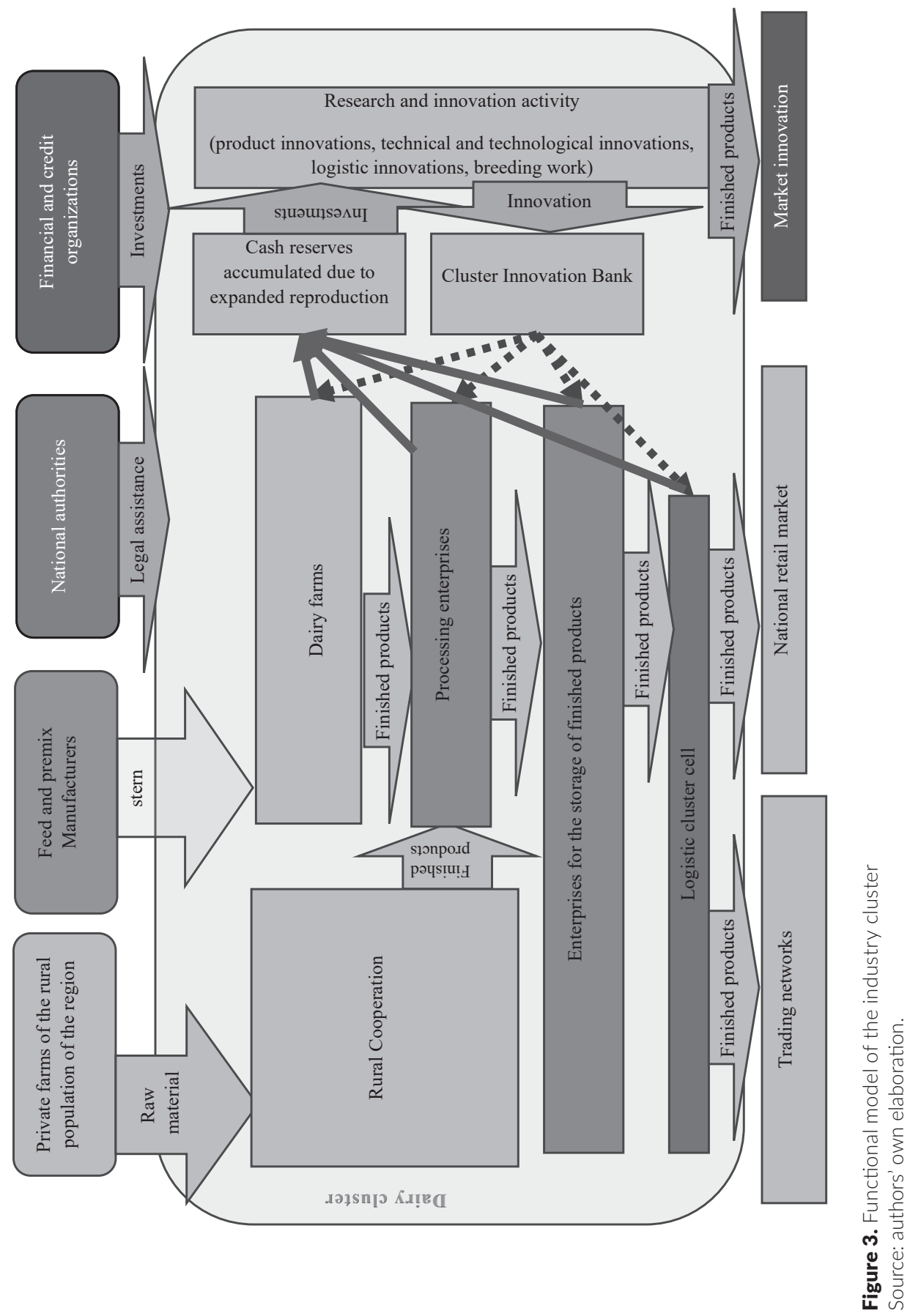


To ensure comprehensive intensification and management of expanded reproduction in a cluster, it is necessary to improve the system and methods of management at agricultural enterprises through the systematic identification and use of reserves for increasing the efficiency of agro-industrial production, processing and sales logistics.

Priority in the field of cluster innovation should be the following areas:

- energy and resource saving technologies for the production, storage and processing of dairy products;

- innovations that make quality food cheaper;

- genetic and breeding work;

- technologies that improve the reliability, durability, efficiency and maintainability of agricultural machinery, parts and mechanisms;

- greening the dairy industry;

- development and improvement of waste-free production cycle;

- production diversification taking into account natural and climatic conditions and relief features;

- improvement of methods of processing, storage and packaging of finished food and convenience foods.

As a result of the integrated fulfillment of tasks and priorities, the model of the science and innovation component will become an organic element of the cluster multisystem (Figure 4). 


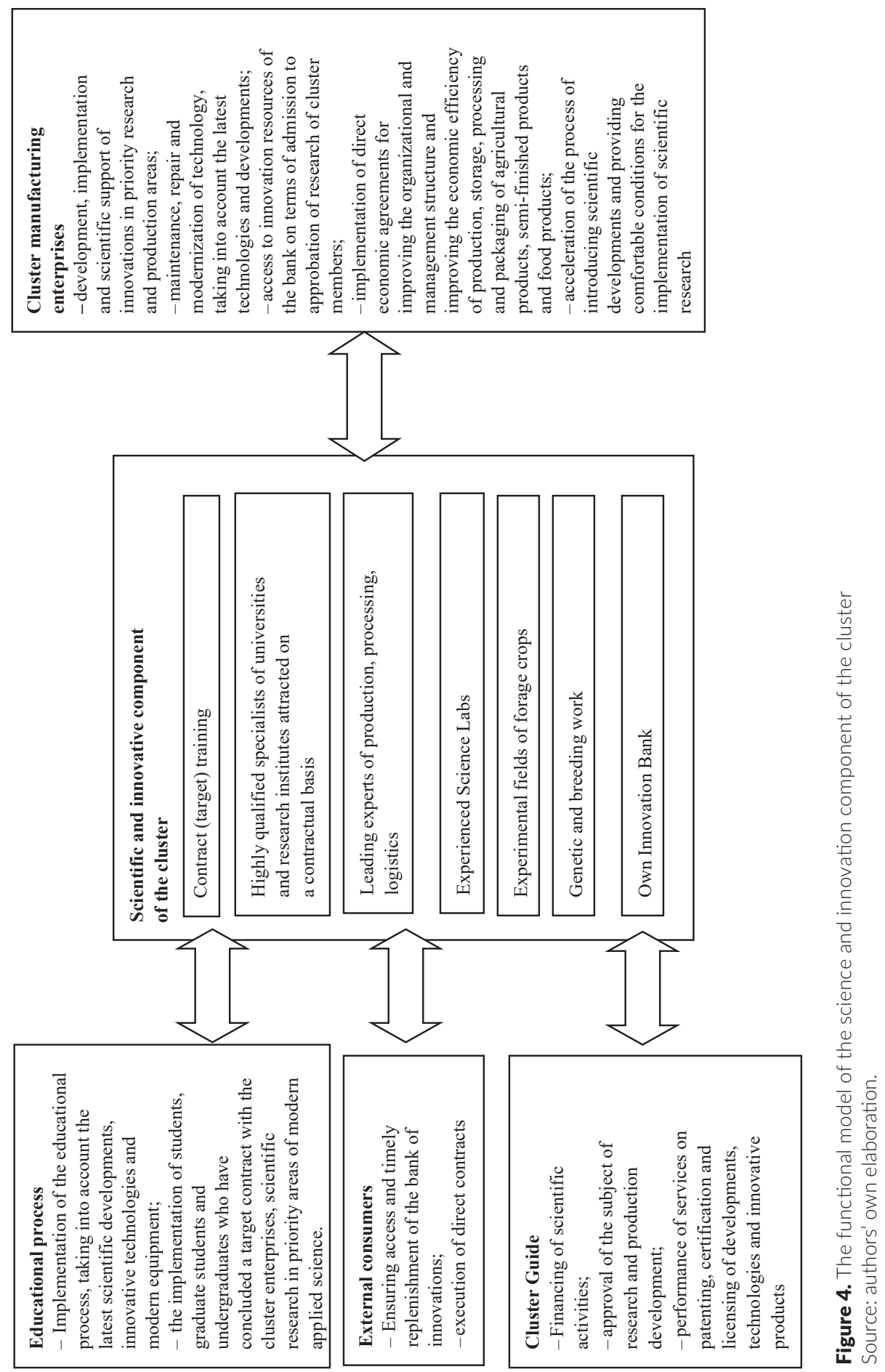




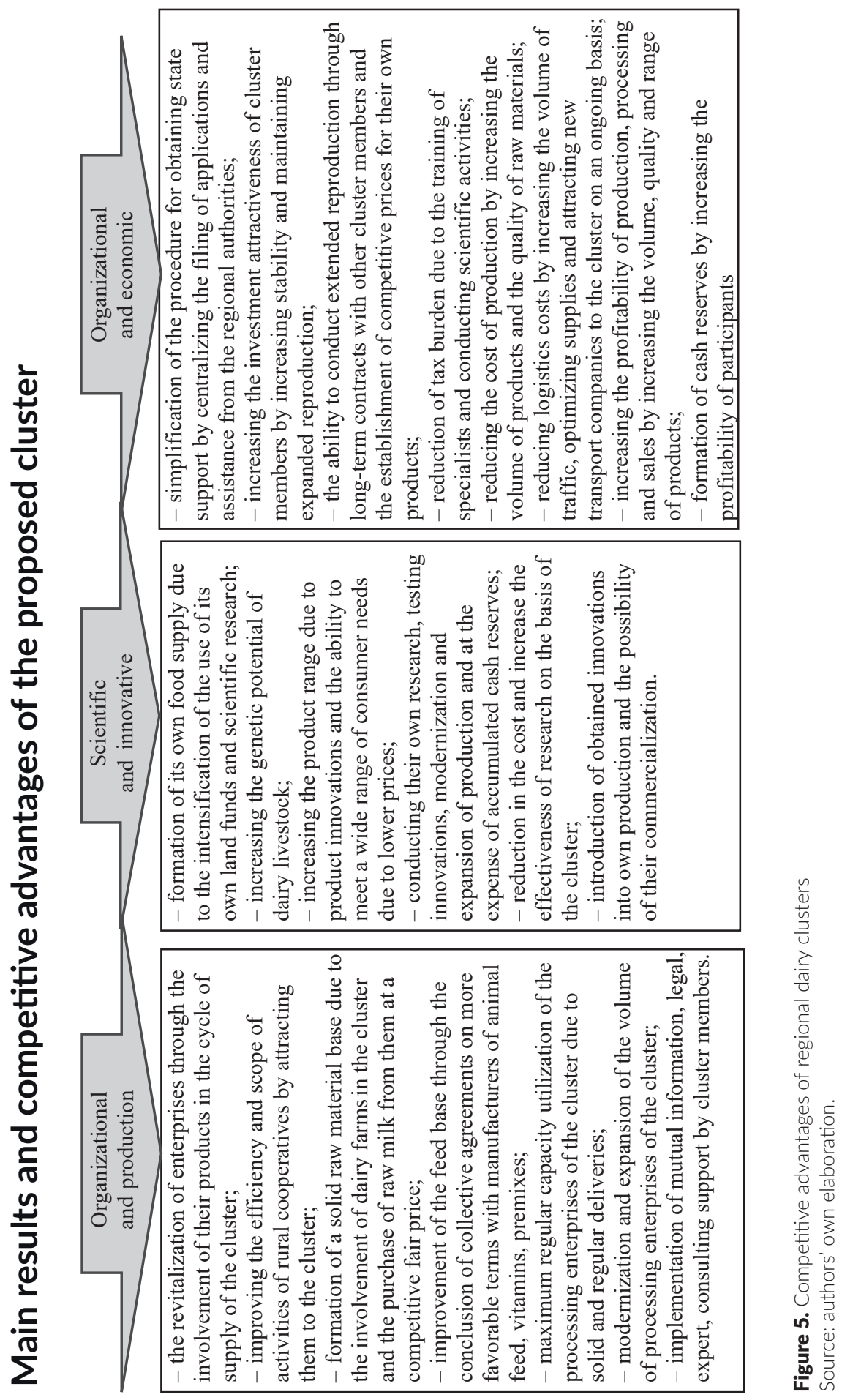




\section{Concluding comments}

The presented model of the dairy-food cluster reflects the system of interrelated relations between its participants, based on consideration of the economic interests of the latter. The model, together with the proposed mechanism, is a complex of organizational and economic principles of system development of integrated and cooperative structures of the region, designed to create deep ties and relations of agricultural production, storage, processing, marketing, service units, functional services and regional governments.

The inclusion of all participants in the agro-industrial complex in the systemic development of integration and cooperation processes will make clear the need to enhance regional dairy industry clustering and cooperation primarily in Russia, the Republic of Belarus and Kazakhstan as the basis for improving the efficiency and competitiveness of enterprises in the region. The implementation of the proposed mechanism increases the efficiency of integration processes, increases production volumes, optimizes the chain of value added formation of dairy products, reduces the trade margin due to the integration of intracluster connections. Systemic development of production and consumer cooperative processes creates opportunities for growth in production and processing of products in small business forms (Ukraine, Turkmenistan), expansion of farm production (Georgia), availability of loans, improvement of sales organization of dairy products by the cluster logistics network, provides for the consolidation and diversification of production and, accordingly, increases efficiency and competitiveness private farms and holding enterprises, processing enterprises, transport and infrastructure companies and their products. As a result, the systemic development of integration and cooperation processes will positively affect the well-being of rural residents and business entities of the industry and the degree of satisfaction of their needs.

\section{References}

Albino, V., Carbonara, N., Giannoccaro, I. (2003), Coordination mechanisms based on cooperation and competition within industrial districts: An agent-based computational approach, "Journal of Artifical Societies and Social Simulation", SimSoc Consortium, United Kingdom, Vol. 6 (4).

Amin, A., Thrift, N. (1996), Globalization, Institutions, and Regional Development in Europe, "European Urban and Regional Studies", Oxford University Press, Oxford.

Andersson, T., Schwaag-Serger, S., Sorvik, J., Hansson, E.W. (2004), The Cluster Policies Whitebook, International organisation for knowledge economy and enterprise development, Malmö, Sweden.

Barkley, D., Henry, M. (2001), Advantages and Disadvantages of Targeting Industry Clusters (REDRL research report 09-2001-01) Regional Economic Development Laboratory, Clemson University, USA. 
Becattini, G. (1990), The Marshallian industrial district as a socio-economic notion, [in:] Pyke F., Becattini G., Sengenberger W. (eds.), Industrial Districts and Inter-firm Cooperation in Italy, International Institute for Labour Studies, Geneva.

Bergman, E.M., Feser, E.J. (1999), Industrial and Regional Clusters: Concepts and Comparative Applications, Regional Research Institute, WVU, Morgantown.

Bergsman, J., Greenston, P., Healy, R. (1975), A classification of economic activities based on location patterns, "Jounal of Urban Economics", Elsevier, Vol. 2 (1).

Borrelli, F., Ponsiglione, C., Iandoli, L., Zollo, G. (2005), Inter-organizational learning and collective memory in small firms clusters: An agent-based approach, "Journal of Artificial Societies and Social Simulation”, SimSoc Consortium, United Kingdom, Vol. 8 (3).

Brenner, T. (2000), The Evolution of Localised Industrial Clusters: Identifying the Processes of Self-Organisation, "Papers on Economics \& Evolution, Jena", MaxPlanck-Institute, Berlin.

Brenner, T. (2000), Industrial Districts: A Typology from an Evolutionary Perspective, "DRUID's Summer 2000 Conference", Rebild, Denmark.

Brenner, T. (2001), Simulating the evolution of localised industrial clusters - an identification of the basic mechanism, "Journal of Artificial Societies and Social Simulation”, SimSoc Consortium, United Kingdom, Vol. 4 (3).

Brenner, T., Emmrich, C., Schlump, C. (2013), Regional Effects of a Cluster-Oriented Policy Measure - The Case of the InnoRegio Program in Germany, Philipps-Universität, Marburg.

Campbell, J. (1974), Selected aspects of the interindustry structure of the state of Washington, "Economic Geography", Taylor \& Francis, Ltd., Vol. 50, No. 1.

Ecotec Research \& Consulting (2001), A Practical Guide to Cluster Development. "A Report to the Department of Trade and Industry and the English RDAs", Ecotec Research \& Consulting, United Kingdom.

Enright, M. (1996), Regional Clusters and Economic Development: A Research Agenda, [in:] Staber, U., Schaefer, N. and Sharma, B., (eds.), Business Networks: Prospects for Regional Development, Walter de Gruyter, Berlin.

Enright, M. (2000), Survey on the Characterization of Regional Clusters: Initial Results (Working Paper), Institute of Economic Policy and Business Strategy: Competitiveness Program University of Hong Kong and the Competitiveness Institute Barcelona, Spain.

Europe INNOVA (2008), The Concept of Clusters and Cluster Policies and Their Role for Competitiveness and Innovation: Main Statistical Results and Lessons Learned (Pro INNO Europe paper No. 9), Office for Official Publications of the European Communities, Luxembourg.

Fagiolo, G., Pyka, A. (2005), Agent-Based Modelling: A Methodology for NeoSchumpeterian Economics, Beitrag Nr. 272, Augsburg.

Feldman, M.P., Francis, J., Bercovitz, J. (2005), Creating a Cluster While Building a Firm: Entrepreneurs and the Formation of Industrial Clusters, "Regional Studies", Taylor \& Francis, Ltd., Vol. 39, Issue 1.

Feser, E.J., Sweeney, S.H. (2002), Theory, methods, and a cross-metropolitan comparison of business clustering [in:] P. McCann (ed.), Industrial Location Economics, Edward Elgar Publishing, Cheltenham. 
Florida, R. (1995), Toward the Learning Region, "Futures", Elsevier Science Ltd, United Kingdom, Vol. 27 (5).

Freeman, C. (1987), Technology Policy and Economic Performance: Lessons from Japan. Pinter, London.

Future Cities (2010) Strategic Clusters in North West Europe, Future Cities Mid-term conference, Essen.

Giardina, I., Bouchaud, J. (2003), Volatility clustering in agent based market models, "Physica A: Statistical Mechanics and its Applications", Elsevier Science Ltd, United Kingdom, Vol. 324, Issues 1-2.

Hausmann, R., Rodrik, D., Velasco, A. (2006), Getting the Diagnosis Right, "Finance \& Development", International monetary fund, Vol. 43 (1).

Hayek, F.A. (1945), The Use of Knowledge in Society, "American Economic Review", American Economic Association, USA, Vol. 35 (4).

Iammarino, S., McCann, Ph. (2006), The Structure and Evolution of Industrial Clusters: Transactions, Technology and Knowledge Spillovers, "Research Policy", Elsevier Science Ltd., United Kingdom, Vol. 35 (7).

Johnston, R. (2003), Clusters: A Review. Mapping Australian Science and Innovation, Australian Centre for Innovation, Sydney.

Ketels, C., Lindqvist, G., Sölvell, Ö. (2006), Cluster Initiatives in Developing and Transition Economies, Center for Strategy and Competitiveness, Stockholm.

Kim, Ch.-W., Lee, K. (2003), Innovation, Technological Regimes and Organizational Selection in Industry Evolution: A "History Friendly Model" of the DRAM industry, "Industrial and Corporate Change", Oxford: Oxford Univ. Press, Vol. 12 (6).

Lindqvist, G., Ketels, C., Sölvell, Ö. (2003), The Cluster Initiative Greenbook, Ivory Tower, Stockholm.

Lundvall, B.-Å., (1993), Explaining Interfirm Cooperation and Innovation: Limits of the Transaction-Cost Approach, [in:] Grabher, G. (ed.), The Embedded Firm, Routledge, London.

Lundvall, B.-Å, Borras, S. (1997), The Globalising Learning Economy: Implications for Innovation Policy, Commission of the European Union, Brussels.

Martin, R., Sunley, P. (2003), Deconstructing Clusters: Chaotic Concept or Policy panacea? "Economic Geography", Taylor \& Francis, Ltd., Vol. 3 (1).

OECD (1999), Boosting Innovation: The Cluster Approach. OECD, Paris

OECD (2007), Competitive Regional Clusters: National Policy Approaches. OECD, Brussels.

Porter, M. (2003), The economic performance of regions, "Regional Studies", Taylor \& Francis, Vol. 37, No. 6/7.

Porter, M. (2003), San Diego: Clusters of Innovation Initiative, MA: Monitor Group, Cambridge.

Porter, M.E. (1990), The Competitive Advantage of Nations, New York: Free Press, New York.

Porter, M.E. (1998), On Competition, Harvard Business School Press, Boston.

Porter, M.E. (2005), Cluster Mapping Project, Strategy and Competitiveness, Harvard Business School, Cambridge. 
PRO INNO Europe (2008), The concept of clusters and cluster policies and their role for competitiveness and innovation: main statistical results and lessons learned. Office for Official Publications of the European Communities, Luxembourg.

Pyke, F., Becattini, G, Sengenberger, W. (1990), Industrial Districts and Interfirm Co-operation in Italy, International Institute for Labour Studies, Geneva.

Quah, D., Simpson, H. (2003), Spatial Cluster Empirics. LSE Economics Department and Institute for Fiscal Studies, London.

Raines, P. (2000), Developing Cluster Policies in Seven European Regions, Regional and Industrial Policy Research Paper, Glasgow, United Kingdom.

Roelandt, T., den Hertog, P. (1999), Cluster Analysis and Cluster-Based Policy, OECD, Paris.

Roepke, H., Adams, D., and Wiseman, R. (1974), A New Approach to the Identification of Industrial Complexes Using Input-Output Data, "Journal of Regional Science", University of Pennsylvania, USA, Vol. 14, Issue 1.

Rosenfeld, S. (1995), Industrial Strength Strategies: Regional Business Clusters and Public Policy, Aspen Institute, Washington, DC.

Rosenfeld, S. (1997), Bringing Business Clusters into the Mainstream of Economic Development, "European Planning Studies", Taylor \& Francis, Vol. 5 (1).

Rosenfeld, S. (2002), A Governor's Guide to Cluster-Based Economic Development, National Governor's Association, Washington, D.C.

Rosenfeld, S. (2002), Creating Smart Systems: A Guide to Cluster Strategies in Less Favoured Regions, European Union, Brussels.

Rosenthal, S., Strange, W. (1999), Geography, Industrial Organization, and Agglomeration, Maxwell School of Public Policy, Syracuse.

Scott, A. (1998), Regions and the World Economy, Oxford University Press, Oxford.

Sengenberger, W., Loveman, G.W., Piore, M.J. (1990), The Re-emergence of Small Enterprises: Industrial Restructuring in Industrialized Countries, International labour organization, Geneva.

Tesfatsion, L. (2005), Agent-based computational economics: a constructive approach to economic theory, Economics Department, Iowa State University, Ames, IA.

Van Dijk, M.P., Sverrisson, A. (2003), Enterprise clusters in developing countries: mechanisms of transition and stagnation, "Entrepreneurship \& Regional Development", Taylor \& Francis, Vol. 15, No. 3.

Vang, J., Chaminade, C. (2006), Building RIS in Developing Countries: Policy Lessons from Bangalore, India, Lund University, Sweden, Vol. 02.

Williams, I. (2010), Cluster Basics: Cluster Development in Twelve Steps, $14^{\text {th }}$ TCI Global Congeferce, Auckland.

Wilson, E.J. III. (2012), How to Make a Region Innovative. "Strategy+Business", PwS network, Issue 66.

Yoon, M., Lee, K. (2009), Agent-based and "History-Friendly" Models for Explaining Industrial Evolution, "Evolutionary and Institutional Economics Review", Springer, Vol. 6 (1).

Zhang, J. (2003), Growing Silicon Valley on a landscape: An agent-based approach to hightest industrial clusters, “Journal of Evolutionary Economics”, Springer, No. 13. 


\section{Streszczenie}

\section{Regionalne aspekty rozwoju klastrowania w branży mleczarskiej}

Artykuł prezentuje wyniki analizy klasycznego i nowoczesnego podejścia do tworzenia regionalnych klastrów rolno-przemysłowych. W obecnych warunkach rynkowych utworzenie klastra w oparciu o istniejącą infrastrukturę regionalną jest niepraktyczne. W większości przypadków klastrami nazywane są struktury holdingowe obejmujące pełny cykl produkcji, przetwarzania i wprowadzania do obrotu produktów rolnych, na przykład „klastry mleczne” - istnieją tradycyjne grupy firm, które formalnie posiadają klasyczne cechy klastra, ale nie dają poszczególnym uczestnikom procesu produkcyjnego wystarczającej autonomii organizacyjnej i prawnej. Zbadano warunki rozwoju innowacji w klastrze, a także mechanizm tworzenia komponentu naukowego i innowacyjnego klastra jako nowopowstałego pełnoprawnego elementu klastra. Wskazano, że klaster powinien być tworzony z zachowaniem podstawowych zasad organizacyjnych i ekonomicznych. W szczególności, podczas gdy w holdingach wynik ekonomiczny działalności służy osiągnięciu celów spółki dominującej, w klastrze należy położyć maksymalny nacisk na wynik i zaspokojenie interesów ekonomicznych wszystkich jego uczestników. Co więcej, zastosowanie klasycznego podejścia do rozwoju klastrów w obecnych warunkach rynkowych może nie być możliwe, a lepsza będzie koncepcja rozwoju klastra przedstawiona przez autora.

Słowa kluczowe: klaster, gospodarka wiejska, mechanizm 